\title{
Skin Adamantinoid Basal Cell Carcinoma
}

National Cancer Institute

\section{Source}

National Cancer Institute. Skin Adamantinoid Basal Cell Carcinoma. NCI Thesaurus. Code C7585.

A rare but aggressive type of basal skin carcinoma. It is characterized by the presence of a meshwork of stellate tumor cells. It occurs most commonly in the nose and ears. 